\title{
PENGARUH UKURAN DEWAN KOMISARIS DAN UKURAN DEWAN DIREKSI TERHARAP NILAI PERUSAHAAN \\ DENGAN KEPEMILIKAN INSTITUSIONAL SEBAGAI \\ VARIABEL MODERASI
}

\author{
Claudia Adelina Thendean, \\ Iren Meita \\ Institut Teknologi dan Bisnis Kalbis \\ claudiathendean@hotmail.com
}

\begin{abstract}
This study aims to determine the effect of Good Corporate Governance on Corporate Value with Intitusional Ownership as a moderating variable. In this study, Good Corporate Governance is measured by 2 variables, namely the size of the board of commissioners and the size of the board of directors. The Company's value is measured by Earning Per Share. The sample of this research is 9 insurance companies listed on Indonesia Stock Exchange period 2011- 2015 period. The results of this study are the size of the board of commissioners and the size of the board of directors does not affect the value of the company; The size of the board of commissioners and the size of the board of directors simultaneously has no effect on the value of the company; Institutional ownership may moderate the size of the board of commissioners to the value of the company; And institutional ownership can moderate the size of the board of directors against corporate value.
\end{abstract}

Keyword: Good Corporate Governance, Board of Commissioner Size, Board of Directors Size, Corporate Value, Earning Per Share (EPS), Institutional Ownership

\section{PENDAHULUAN}

Perusahaanasuransi merupakan salah satu lembaga keuangan non bank yang bergerak dalam bidang jasa dan dapat dijadikan sebagai salah satu pilar perekonomian di Indonesia, karena perkembangan perusahaan asuransi dapat memberikan pengaruh pada kondisi dan pertumbuhan ekonomi baik dibidang perdagangan maupun jasa. Penerapan Good Corporate Governance diperlukan agar perusahaan asuransi dikelola secara amanah efisien, professional, dan tidak merugikan kepentingan stakeholders (Indah et al., 2006: 142-148).

Nilai perusahaan sangat penting karena mencerminkan kinerja perusahaan yang dapat mempengaruhi persepsi investor terhadap perusahaan. Nilai perusahaan dapat memberi kemakmuran pemegang saham secara maksimum apabila harga saham tersebut meningkat. Semakin banyak peningkatan harga saham sebuah perusahaan, maka makin maksimum pula kemakmuran pemegang saham sehingga menarik investor untuk menanam saham. Nilai perusahaan yang tercermin pada harga saham memiliki arti bahwa semakin tinggi harga saham perusahaan maka semakin tinggi pula nilai perusahaan tersebut. Nilai perusahaan yang tinggi dapat meningkatkan kemakmuran bagi para pemegang saham, sehingga para pemegang saham akan menginvestasikan modalnya kepada perusahaan tersebut (Haruman, 2008 dalam Permanasari, 2010:1).

Perusahaan cenderung bergantung pada modal dari pihak eksternal untuk membiayai kegiatan operasionalnya. Perusahaan perlu meyakinkan pihak penyandang dana eksternal bahwa investasi mereka digunakan secara tepat dan efisien. Manajemen juga memastikan bahwa manajemen bertindak terbaik untuk kepentingan perusahaan. Kepastian seperti itu diberikan oleh sistem tata kelola. Sistem 
corporate governance yang baik memberikan perlindungan efektif kepada pemegang saham dan kreditor sehingga mereka yakin akan memperoleh kembali investasinya dengan wajar dan bernilai tinggi (Cahyani Nuswandari,2009:71).

Good Corporate Governance merupakan tata kelola perusahaan yang menjelaskan hubungan antara berbagai partisipan dalam perusahaan yang menentukan arah kinerja perusahaan. Isu mengenai good corporate governance mulai mengemuka, khususnya di Indonesia pada tahun 1998 ketika Indonesia mengalami krisis yang berkepanjangan. Banyak pihak yang mengatakan lamanya proses perbaikan di Indonesia disebabkan oleh sangat lemahnya good corporate governance yang diterapkan dalam perusahaan di Indonesia. Sejak saat itu, baik pemerintah maupun investor mulai memberikan perhatian yang cukup signifikan dalam praktek good corporate governance.

Corporate governance yang lemah menjadi salah satu penyebab terjadinya peritiwa-peristiwa penting tersebut. Ciri utama dari lemahnya corporate governance adalah adanya tindakan mementingkan diri sendiri di pihak manajer perusahaan (Darmawati et al, 2005:65). Investor sebagai principal, mempercayakan dananya kepada perusahaan dan tidak bertanggung jawab dalam pengambilan keputusan dan operasional perusahaan. Tetapi manajer sebagai agent, melakukan manipulasi demi kepentingannya sendiri, sehingga membuat investor kehilangan kepercayaan dan menyebabkan penarikan dana oleh investor atas dana yang telah ditanam sebelumnya.

Corporate governance berkembang dengan bertumpu pada agency theory, dimana pengelolaan perusahaan harus diawasi dan dikendalikan untuk memastikan bahwa pengelolaan tersebut dilakukan dengan penuh kepatuhan kepada peraturan dan ketentuan yang berlaku. Nilai perusahaan yang tinggi dapat meningkatkan kemakmuran pemegang saham, sehingga pemegang saham akan menginvestasikan modalnya ke perusahaan tersebut.

Corporate governance merupakan pedoman bagi manajer untuk mengelola perusahaan secara best practice. Manajer akan membuat keputusan keuangan yang dapat menguntungkan semua pihak (stakeholder). Manajer bekerja secara efektif dan efisien sehingga dapat menurunkan biaya modal dan mampu meminimalkan risiko. Usaha tersebut diharapkan menghasilkan profitabilitas yang tinggi. Investor akan memperoleh pendapatan (return) sesuai dengan harapan. Laba per saham meningkat sehingga saham perusahaan banyak diminati oleh investor. Hal ini akan mengakibatkan nilai perusahaan meningkat (Cahyani Nuswandari,2009:72).

Pelaksanaan corporate governance yang baik dan sesuai dengan peraturan yang berlaku akan membuat investor merespon secara positif terhadap kinerja perusahaan dan meningkatkan nilai pasar perusahaan. Penelitian ini bertujuan untuk menginvestigasi mengenai pengaruh Corporate Governance Perception Index (CGPI) terhadap kinerja pasar dan kinerja operasional perusahaan pada perusahaan yang terdaftar di Bursa Efek Jakarta, sekarang Bursa Efek Indonesia (Cahyani Nuswandari, 2009:75).

Hanas (2009:17) menyatakan bahwa board adalah pimpinan pada organisasi yang memiliki tanggungjawab untuk mengendalikan dan mengawasi pemakaian sumber daya agar sesuai dan sejalan dengan tujuan organisasi yang telah ditetapkan oleh organisasi. Board yang dimaksudkan dalam konteks perusahaan Indonesia adalah dewan komisaris dan dewan direksi. Dewan direksi dan dewan komisaris adalah pihak yang bertanggung jawab dan memiliki otoritas penuh dalam membuat keputusan tentang melakukan pengarahan, pengendalian, dan pengawasan atas pengelolaan sumber daya agar sesuai dengan tujuan perusahaan.

Fauzan et al. (2012:66) menyatakan bahwa menurut Jensen dan Meckling (1976) kepemilikan institusional memiliki peranan yang sangat penting dalam meminimalisasi konflik keagenan yang terjadi antara manajer dan pemegang saham. Keberadaan investor institusional dianggap mampu menjadi mekanisme monitoring yang efektif dalam setiap keputusan yang diambil oleh manajer. Hal ini disebabkan investor institusional terlibat dalam pengambilan yang strategis sehingga tidak mudah percaya terhadap tindakan manipulasi laba. 


\section{KERANGKA TEORI}

\subsection{Teori Keagenan (Agency Theory)}

Menurut Jensen dan Meckling (1986) dalam Hardiningsih dan Oktaviani (2012:14), Teori keagenan dalam manajemen keuangan membahas adanya hubungan agency, yaitu hubungan mengenai adanya pemisahan antara kepemilikan dan pengelolaan yang dilakukan oleh manajer. Manajemen pihak yang diberikan kewenangan oleh pemilik perusahaan untuk mengelola perusahaan namun dalam kenyataanya jika perusahaan tidak memperoleh hasil yang menggembirakan seharusnya pemilik modal bisa memutuskan untuk mengganti manajemen yang tidak meningkatkan kemakmuran.

Kusumaningtyas (2015:3), Teori keagenan dapat menjelaskan bagaimana pihak-pihak yang terlibat dalam perusahaan akan berperilaku, karena pada dasarnya antara agent dan principal memiliki kepentingan yang berbeda yang menyebabkan terjadinya konflik keagenan (agent conflict). Pada dasarnya, konflik keagenan terjadi karena adanya pemisahan antara kepemilikan dan pengendalian perusahaan. Adanya konflik kepentingan antara investor dan manajer menyebabkan munculnya agency cost yaitu biaya monitoring (monitoring cost) yang dikeluarkan oleh principal.

\section{METODE PENELITIAN}

\subsection{Jenis Penelitian}

Penelitian ini merupakan penelitian dengan metode kuantitatif. Menurut Sugiyono (2012:7), metode penelitian kuantitatif dapat diartikan sebagai metode penelitian yang berlandaskan pada filsafat positivisme, digunakan untuk meneliti pada populasi atau sampel tertentu. Teknik pengambilan sampel pada umumnya dilakukan secara random, pengumpulan data menggunakan instrumen penelitian, analisis data bersifat kuantitatif/statistik dengan tujuan untuk menguji hipotesis yang telah ditetapkan.

\subsection{Sumber Data}

Dalam penelitian ini jenis data yang digunakan adalah data sekunder. Data sekunder adalah datadata yang diambil dari catatan atau sumber lain yang telah ada sebelumnya. Data sekunder yang digunakan merupakan data laporan tahunan perusahaan asuransi tahun 2011-2015. Data diperoleh dari pojok Bursa Efek Indonesia (BEI) Fakultas Ekonomi Kalbis Institute dan dari website www.idx.co.id.

\subsection{Populasi dan Sampel}

Teknik pengambilan sampel pada penelitian ini adalah non probability sampling dengan teknik purposive sampling. Pada penelitian ini, sampel yang didapat dari seluruh perusahaan- perusahaan asuransi yang terdaftar di Bursa Efek Indonesia sejumlah 9 perusahaan dari 12 perusahaan.

\subsection{Variabel Penelitian}

Terdarapat 4 variabel dalam penelitian ini, ukuran dewan komisaris dan ukuran dewan direksi sebagai variabel independen, nilai perusahaan sebagai variabel dependen, dan kepemilikan institusional sebagai variabel moderasi.

\subsection{Model Penelitian}

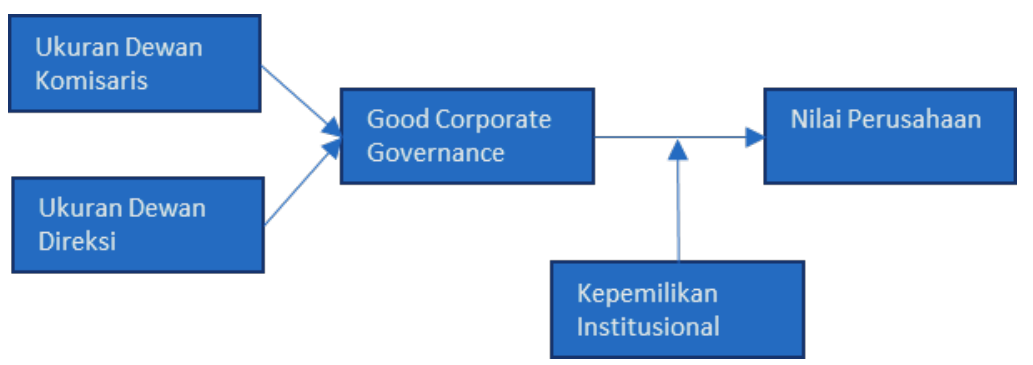

Gambar 1 Model Penelitian 
Kerangka konseptual diatas menunjukkan Kepemilikan Institusional sebagai variabel moderasi dimana Kepemilikan Institusional dapat memperkuat atau memperlemah pengaruh antar variabel independen yaitu ukuran dewan komisaris dan ukuran dewan direksi dengan variabel dependen yaitu nilai perusahaan.

\subsection{Metode Analisis Data}

Setelah data yang dibutuhkan dalam penelitian ini terkumpul, kemudian melakukan analisis data yang terdiri dari uji asumsi klasik, dan uji hipotesis. Uji asumsi klasik terdiri dari uji normalitas, uji multikolinieritas, uji autokolerasi dan uji heteroskedastisitas. Kemudian untuk menguji hipotesis menggunakan analisis regresi linear berganda. Uji hipotesis dibagi kembali menjadi 3, yaitu uji koefisien determinasi, uji statistik t (parsial), dan uji analisis jalur.

\subsection{Analisis Regresi Linear Berganda}

Uji regresi berganda dilakukan untuk mengetahui pengaruh variabel $\mathrm{X}$ dengan variabel $\mathrm{Y}$ dan variabel Z. Dengan persamaan analisis regresi berganda yang dirumuskan sebagai berikut:

Persamaan 1: $\quad \mathrm{Y}_{1}=\boldsymbol{\alpha}+\boldsymbol{\beta} 1 \mathrm{X} 1+\boldsymbol{\beta}_{2} \mathrm{X} 1 \mathrm{Z}+\varepsilon$

Persamaan 2: $\quad \mathrm{Y}_{2}=\boldsymbol{\alpha}+\boldsymbol{\beta} 1 \mathrm{X}_{2}+\boldsymbol{\beta}_{2} \mathrm{X}_{2} \mathrm{Z}+\varepsilon$

Persamaan 3: $\quad \mathrm{Y}_{3}=\boldsymbol{\alpha}+\boldsymbol{\beta} 1 \mathrm{X}_{1}+\boldsymbol{\beta}_{2} \mathrm{X}_{2}+\varepsilon$

Keterangan :

$\mathrm{Y} \quad=$ Nilai Perusahaan

$\mathrm{X} 1=$ Ukuran Dewan Komisaris

X2 = Ukuran Dewan Direksi

$\beta 1, \beta 2=$ Koefisien regresi

$\mathrm{Z} \quad=$ Kepemilikan Institusional

\section{PEMBAHASAN}

\subsection{Hasil Uji Asumsi Klasik}

\subsubsection{Hasil Uji Normalitas}

Pengujian statistik dalam penelitian ini menggunakan uji statistik One Sample KolmogorovSmirnov. Residual dinyatakan terdistribusi normal jika nilai signifikansi Kolmogorov-Smirnov > 0,05. Berikut adalah hasil pengujian normlaitas dengan uji statistik Kolmogorov-Smirnov :

Tabel 1 Hasil Uji Normalitas

\begin{tabular}{llr}
\hline & & Unstandardized Residual \\
\hline $\mathrm{N}$ & & 45 \\
Normal Parameters & Mean &, 0000000 \\
& Std. & 133,89091840 \\
& Deviation &, 115 \\
Most Extreme Differences & Absolute &, 115 \\
& Positive &,- 061 \\
& Negative &, 115 \\
Test Statistic & &, 164 \\
Asymp. Sig. (2-tailed) & & \\
\hline
\end{tabular}

Berdasarkan table 1, dapat disimpulkan bahwa hasil uji normalitas dengan menggunakan uji statistic (I-Sample-K-S) menunjukkan nilai signifikansi (2-Tailed) sebesar 0,164. Hasil penelitian ini menunjukkan bahwa tingkat signifikansi di atas 0,05 maka berarti data yang diuji normal. 
Sehingga dapat disimpulkan bahwa model regresi telah memenuhi asumsi normalitas.

\subsubsection{Hasil Uji Multikolinearitas}

Uji Multikolinearitas bertujuan untuk menguji apakah model regresi ditemukan adanya korelasi antar variable bebas (independen). Berikut ini adalah hasil pengujian multikolinearitas dapat dilihat pada tabel 2 :

Tabel 2. Hasil Uji Multikolinearitas

\begin{tabular}{llcr}
\hline Model & & \multicolumn{2}{c}{ Collinearity Statistics } \\
\cline { 3 - 4 } & & Tolerance & VIF \\
\hline 1 & (Constant) & & \\
& Ukuran Dewan Komisaris &, 959 & 1,043 \\
& Ukuran Dewan Direksi &, 922 & 1,085 \\
& Kepemilikan Institusional &, 931 & 1,074 \\
\hline
\end{tabular}

Pada tabel 2 dapat dilihat bahwa variabel Ukuran dewan komisaris, Ukuran dewan direksi, dan Kepemilikan institusional memiliki nilai tolerance berturut-turut sebesar0,959, 0,922, dan 0,931 yang menunjukkan bahwa nilai Tolerance $>0,10$. Sementara itu nilai VIF dari variabelvariabel tersebut secara berturut-turut adalah $1,043,1,085$, dan 1,074 yang menunjukkan bahwa nilai VIF $<10$. Hal ini berarti bahwa tidak terjadi multikolinearitas. Sehingga model regresi dapat digunakan untuk memprediksi nilai perusahaan selama periode penelitian.

\subsubsection{Hasil Uji Heteroskedastisitas}

Uji statistik yang juga dilakukan oleh peneliti untuk mendeteksi ada atau tidaknya heteroskedastisitas adalah uji white. Uji white ini bertujuan untuk mendeteksi ada atau tidaknya heteroskedastisitas dengan cara membandingkan nilai chi square hitung dengan chi square tabel. Jika nilai chi square hitung lebih kecil dari chi square tabel maka tidak terdapat masalah heteroskedastisitas, jika nilai chi square hitung lebih besar dari chi square tabel maka terdapat masalah heteroskedastisitas pada variabel data.

Tabel 3. Hasil Uji Koefisien Determinasi $\left(\mathrm{R}^{2}\right)$

\begin{tabular}{cccc}
\hline Model & R & R Square & Adj. R Square \\
\hline 1 &, $489^{\mathrm{a}}$ &, 239 &, 119 \\
\hline
\end{tabular}

Uji heteroskedastisitas menggunakan uji White atau uji Chi- Square. Berdasarkan hasil tabel menunjukkan bahwa nilai R2 sebesar 0,239. Kemudian, mencari nilai chi- square dengan cara : $\mathrm{n}$ $\mathrm{x} \mathrm{R} 2=45 \times 0,239=10,755$. Nilai $C^{2}$ tabel bisa dicari didalam Excel dengan rumus $=\mathrm{CHIINV}(($ Probability; degree of Freedom $)$ atau $=\mathrm{CHIINV}($ Batas Kritis Derajat Kepercayaan; Derajat Kebebasan), yang berarti $=\operatorname{CHIINV}(0.05,45)$ maka hasilnya 616,562 . Nilai $C^{2}$ hitung $10,75<616,56 C^{2}$ tabel. Maka berdasarkan perhitungan tersebut dapat disimpulkan bahwa nilai $C^{2}$ hitung $<C^{2}$ tabel, yang berarti tidak terdapat masalah heteroskedastisitas pada model regresi.

\subsubsection{Hasil Uji Autokorelasi}

Berdasarkan tabel 4 dibawah ini hasil runs test menunjukan bahwa nilai Asymp. Sig. (2tailed) $>$ dari 0,05 yaitu 0,367 , yang berarti data yang dipergunakan cukup random sehingga tidak terdapat masalah autokorelasi pada data yang diuji. 
Tabel 4 Hasil Uji Autokorelasi

Runs Test

\begin{tabular}{lr}
\hline & Unstandardized Residual \\
\hline Test Value & 1.53186 \\
Cases $<$ Test Value & 22 \\
Cases $>=$ Test Value & 23 \\
Total Cases & 45 \\
Number of Runs & 20 \\
$Z$ &,- 902 \\
Asymp. Sig. (2-tailed) &, 367 \\
\hline a. Median &
\end{tabular}

\subsection{Hasil Analisis Regresi Linear Berganda}

Model analisis yang digunakan adalah analisis linear berganda karena dalam penelitian ini menggunakan lebih dari satu variabel independen. Dengan menggunakan bantuan program SPSS versi 23, hasil perhitungannya sebagai berikut:

Tabel 5. Hasil Uji Persamaan Regresi 1

\begin{tabular}{rlrrr}
\hline \multicolumn{1}{c}{ Model } & \multicolumn{2}{c}{$\begin{array}{c}\text { Unstandardized } \\
\text { Coefficients }\end{array}$} & $\begin{array}{c}\text { Standardized } \\
\text { Coefficients }\end{array}$ \\
& B & Std. Error & Beta \\
\hline & (Constant) & 199,669 & 83,650 & \\
1 & Ukuran Dewan & 55,069 & 29,031 &, 305 \\
& Komisaris & 102,999 & 22,249 &,- 745 \\
\hline
\end{tabular}

Sumber : data sekunder yang diolah

Berdasarkan pada tabel 5, dapat diketahui nilai konstanta dan koefisien regresi sehingga dapat disusun persamaan regresi linear berganda yang pertama adalah sebagai berikut:

$$
\mathrm{Y}=199,669+55,069 \mathrm{X}_{1}-102,999 \mathrm{X}_{1} \mathrm{Z}+\varepsilon
$$

Berdasarkan regresi linear diatas, dapat di interpretasikan koefisien regresi dari masingmasing variabel independen sebagai berikut:

a. Konstanta sebesar 199,669; artinya jika variabel ukuran dewan komisaris (X1) nilainya adalah 0, maka nilai perusahaan sebesar 199,669.

b. Koefisien regresi variabel ukuran dewan komisaris (X1) sebesar 55,069 artinya jika variabel lain nilainya tetap dan ukuran dewan komisaris mengalami kenaikan satu orang, maka nilai perusahaan (Y) akan mengalami kenaikan sebesar 55,069. Koefisien bernilai positif ini menunjukkan bahwa variabel ukuran dewan komisaris mempunyai hubungan searah dengan nilai perusahaan. Hal ini berarti bahwa semakin tinggi ukuran dewan komisaris, maka semakin meningkatkan nilai perusahaan.

c. Koefisien regresi variabel moderasi (Ukuran dewan komisaris x Kepemilikan Institusional) sebesar -102,999; artinya jika variabel lain nilainya tetap sedangkan ukuran dewan komisaris dan kepemilikan institusional mengalami kenaikan 1\%, maka nilai perusahaan akan mengalami penurunan sebesar 102,999. Koefisien bernilai negative ini menunjukkan bahwa variabel proporsi ukuran dewan komisaris mempunyai hubungan yang berlawanan arah 
dengan nilai perusahaan. Hal ini berarti bahwa semakin tinggi proporsi ukuran dewan komisaris, maka semakin menurun nilai perusahaan.

Tabel 6. Hasil Uji Persamaan Regresi 2

\begin{tabular}{rlrrr}
\hline & & \multicolumn{2}{c}{ Unstandardized } & \multicolumn{2}{c}{ Standardized } \\
& Model & \multicolumn{2}{c}{ Coefficients } & Coefficients \\
& & B & Std. Error & Beta \\
\hline \multirow{2}{*}{1} & (Constant) & 141,415 & 103,947 & \\
& Ukuran Dewan & 58,694 & 25,517 &, 283 \\
& Direksi & $-85,358$ & 18,009 &,- 582 \\
\cline { 2 - 5 } & $\mathrm{X}_{2} \mathrm{Z}$ & \multicolumn{3}{c}{}
\end{tabular}

Berdasarkan pada tabel 6, dapat diketahui nilai konstanta dan koefisien regresi sehingga dapat disusun persamaan regresi linear berganda yang kedua adalah sebagai berikut:

$$
\mathrm{Y}=141,41+58,69 \mathrm{X} 2-85,35 \mathrm{X} 2 \mathrm{Z}
$$

Berdasarkan regresi linear diatas, dapat di interpretasikan koefisien regresi dari masingmasing variabel independen sebagai berikut:

a. Konstanta sebesar 141,41 artinya jika variabel ukuran dewan direksi (X2) nilainya adalah 0, maka nilai perusahaan sebesar 141,41.

b. Koefisien regresi variabel ukuran dewan direksi (X2) sebesar 58,69 artinya jika variabel lain nilainya tetap dan ukuran dewan direksi mengalami kenaikan 1 orang, maka nilai perusahaan (Y) akan mengalami kenaikan sebesar 58,69. Koefisien bernilai positif ini menunjukkan bahwa variabel ukuran dewan komisaris mempunyai hubungan searah dengan nilai perusahaan. Hal ini berarti bahwa semakin tinggi ukuran dewan direksi, maka semakin meningkat nilai perusahaan.

c. Koefisien regresi variabel moderasi (Ukuran dewan direksi x Kepemilikan Institusional) sebesar $-85,35$ artinya jika variabel lain nilainya tetap sedangkan ukuran dewan direksi dan kepemilikan institusional mengalami kenaikan 1\%, maka nilai perusahaan akan mengalami penurunan sebesar 85,35. Koefisien bernilai negatif ini menunjukkan bahwa variabel proporsi ukuran dewan direksi mempunyai hubungan yang berlawanan arah dengan nilai perusahaan. Hal ini berarti bahwa semakin tinggi proporsi ukuran dewan direksi, maka semakin menurun nilai perusahaan.

Tabel 7. Hasil Uji Persamaan Regresi 3

\begin{tabular}{|c|c|c|c|c|}
\hline \\
\hline & \multirow[t]{2}{*}{ Model } & \multicolumn{2}{|c|}{$\begin{array}{l}\text { Unstandardized } \\
\text { Coefficients }\end{array}$} & \multirow{2}{*}{$\begin{array}{c}\text { Standardized } \\
\text { Coefficients } \\
\text { Beta }\end{array}$} \\
\hline & & B & Std. Error & \\
\hline \multirow{3}{*}{1} & (Constant) & 131.371 & 144.356 & \\
\hline & $\begin{array}{l}\text { Ukuran Dewan } \\
\text { Komisaris }\end{array}$ & -37.030 & 26.939 & -.205 \\
\hline & $\begin{array}{l}\text { Ukuran Dewan } \\
\text { Direksi }\end{array}$ & 49.273 & 30.996 & .237 \\
\hline
\end{tabular}

Sumber: Data Telah Diolah Peneliti

Berdasarkan pada tabel 7 , dapat diketahui nilai konstanta dan koefisien regresi sehingga dapat disusun persamaan regresi linear berganda yang ketiga adalah sebagai berikut:

$$
\mathrm{Y}=131,37-37,03 \mathrm{X}_{1}+49,27 \mathrm{X}_{2}
$$

Berdasarkan regresi linear diatas, dapat di interpretasikan koefisien regresi dari masingmasing variabel independen sebagai berikut:

a. Konstanta sebesar 131,37 artinya jika variabel ukuran dewan direksi (X2) nilainya adalah 0 , 
maka nilai perusahaan sebesar 131,37.

b. Koefisien regresi variabel ukuran dewan komisaris (X1) sebesar -37,03 artinya jika variabel lain nilainya tetap dan ukuran dewan komisaris mengalami kenaikan 1 orang, maka nilai perusahaan (Y) akan mengalami penurunan sebesar 37,03. Koefisien bernilai negatif ini menunjukkan bahwa variabel ukuran dewan komisaris mempunyai hubungan berlawanan arah dengan nilai perusahaan. Hal ini berarti bahwa semakin tinggi ukuran dewan komisaris, maka semakin menurun nilai perusahaan.

c. Koefisien regresi variabel ukuran dewan direksi (X2) sebesar 49,27 artinya jika variabel lain nilainya tetap dan ukuran dewan direksi mengalami kenaikan 1 orang, maka nilai perusahaan (Y) akan mengalami kenaikan sebesar 49,27. Koefisien bernilai positif ini menunjukkan bahwa variabel ukuran dewan direksi mempunyai hubungan searah dengan nilai perusahaan. Hal ini berarti bahwa semakin tinggi ukuran dewan komisaris, maka semakin meningkat nilai perusahaan.

\subsection{Hasil Uji Hipotesis}

\subsubsection{Uji Koefisien Determinan}

Hasil uji koefisien determinasi adalah seperti tersaji pada table 8 berikut ini. Tabel 8. Hasil Uji Koefisien Determinasi $\left(\mathrm{R}^{2}\right)$

\begin{tabular}{ccc}
\hline Model & R & Adj. R Square \\
\hline 1 &, $626^{\text {a }}$ &, 313 \\
\hline
\end{tabular}

Dari tabel 8, menunjukkan nilai adjusted $R^{2}$ sebesar 0,313 yang berarti variabel nilai perusahaan mampu dijelaskan oleh Good Corporate Governance yang meliputi ukuran Dewan Komisaris dan Ukuran Dewan Direksi sebesar 0,313 atau 31,3\% sedangkan selebihnya 68,7\% dijelaskan oleh faktor lain yang tidak diteliti dalam penelitian ini.

\subsubsection{Uji Signifikansi Simultan (Uji Statistik F)}

Hasil uji signifikansi simultan adalah seperti tersaji pada table 9 berikut ini.

Tabel 9. Hasil Uji Simultan

\begin{tabular}{llcc}
\hline & Model & F & Sig. \\
\hline 1 & $\begin{array}{l}\text { Regression } \\
\text { Residual } \\
\text { Total }\end{array}$ & 1,932 &, $158^{\mathrm{b}}$ \\
\hline
\end{tabular}

Dari tabel 9, diketahui bahwa $\mathrm{F}$ hitung yang diperoleh sebesar 1,932 sedangkan $\mathrm{F}$ tabel sebesar 3,20 yang dihitung dengan menggunakan Ms. Excel dengan tingkat signifikansi 0,158. Dari hasil tersebut, maka diketahui $\mathrm{F}$ hitung $<\mathrm{F}$ tabel, dengan nilai signifikansi 0,1158 $>0,05$. Maka dapat disimpulkan bahwa ukuran dewan komisaris dan ukuran dewan direksi secara bersama- sama tidak berpengaruh signifikan terhadap nilai perusahaan.

\subsubsection{Uji Signifikansi Individu (Uji Statistik t)}

Hasil uji signifikansi parsial adalah seperti tersaji pada table 10 berikut ini.

Tabel 10. Hasil Uji Parsial (Uji t)

\begin{tabular}{|c|c|c|c|}
\hline & Model & $\mathrm{t}$ & Sig. \\
\hline \multirow{3}{*}{1} & (Constant) & 0,910 & ,368 \\
\hline & Ukuran Dewan Komisaris & 1,375 & 177 \\
\hline & Ukuran Dewan Direksi & 1,590 & 199 \\
\hline
\end{tabular}

Berdasarkan tabel 10 dapat disimpulkan sebagai berikut : 
a. Ukuran Dewan Komisaris Variabel ukuran dewan komisaris memiliki nilai sig-t 0,177 yang lebih besar dari 0,05. Hal ini menunjukkan bahwa ukuran dewan komisaris tidak berpengaruh signifikan terhadap nilai perusahaan (earning per share).

b. Ukuran Dewan Direksi Variabel ukuran dewan direksi memiliki nilai sig-t 0,119 yang lebih besar dari 0,05. Hal ini menunjukkan bahwa ukuran dewan komisaris tidak berpengaruh signifikan terhadap nilai perusahaan (earning per share).

\subsubsection{Uji Moderasi}

Hasil uji Multiple Regression Analysis (MRA) adalah seperti tersaji pada table 11 berikut ini.

Tabel 11. Hasil Uji MRA

\begin{tabular}{llcc}
\hline Model & $\mathrm{t}$ & \multicolumn{1}{c}{ Sig } \\
\hline 1 & (Constant) &, 575 &, 568 \\
& Ukuran Dewan Komisaris &, 320 &, 751 \\
& Ukuran Dewan Direksi &, 982 &, 332 \\
& Kepemilikan Institusional &, 055 &, 956 \\
& MODERAT 1 &, 047 &, 963 \\
& MODERAT 2 &, 710 &, 482 \\
\hline
\end{tabular}

Sumber: Data Telah Diolah Peneliti

Pada tabel 11 diperoleh nilai signifikan sebesar 0,963 dan 0,482 yang keduanya lebih besar dari 0,05 , sehingga dapat dikatakan bahwa kepemilikan institusional tidak dapat memoderasi pengaruh antara ukuran dewan komisaris dengan nilai perusahaan (Earning Per Share) dan ukuran dewan direksi dengan nilai perusahaan (Earning Per Share).

\section{SIMPULAN DAN SARAN}

\subsection{Simpulan}

Berdasarkan hasil penelitian yang telah dilakukan mengenai pengaruh ukuran dewan direksi dan ukuran dewan komisaris terhadap nilai perusahaan yang dimoderasi oleh kepemilikan institusional dengan data sampel penelitian perusahaan asuransi yang berada di Bursa Efek Indonesia selama periode 2011-2015, maka dapat disimpulkan:

a. Ukuran Dewan Komisaris tidak berpengaruh secara signifikan terhadap Nilai Perusahaan karena hasil uji menunjukkan nilai sig-t 0,177 yang lebih besar dari 0,05 (H1 ditolak).

b. Ukuran Dewan Direksi tidak berpengaruh secara signifikan terhadap Nilai Perusahaan karena hasil uji menunjukkan nilai sig-t 0,119 yang lebih besar dari 0,05 (H2 ditolak).

c. Kepemilikan Institusional dapat memoderasi Dewan Komisaris terhadap Nilai Perusahaan karena hasil uji menunjukkan nilai signifikan sebesar 0,963 yang lebih besar dari 0,05 (H3 ditolak).

d. Kepemilikan Institusional dapat memoderasi Dewan Direksi terhadap Nilai Perusahaan karena hasil uji menunjukkan nlai signifikan sebesar 0,482 yang lebih besar dari 0,05 (H4 ditolak).

\subsection{Saran}

Berdasarkan penelitian yang telah dilakukan oleh peneliti, saran yang dapat diberikan untuk penelitian-penelitian selanjutnya sebagai berikut:

a. Memperluas jangka waktu penelitian agar hasil bisa lebih relevan.

b. Penelitian selanjutnya dapat mengganti proxy variabel dependen dengan proxy lainya misalnya tobins $q$ atau price earning ratio agar dapat mengetahui pengaruh ukuran dewan direksi dan ukuran dewan komisaris terhadap proxy nilai perusahaan lainnya.

c. Data atau sampel untuk penelitian selanjutnya juga bisa menggunakan industri-industri lain seperti perusahaan manufaktur, perbankan makanan dan minuman.

d. Penelitian selanjutnya dapat menambahkan atau mengganti indikator variabel independen dengan indikator lainya misalnya kepemilikan manajerial dan komite audit agar dapat 
mengetahui nilai perusahaan dapat berjalan dengan baik dengan adanya pengaruh indikator variabel Good Corporate Governance yang lain.

\section{DAFTAR PUSTAKA}

Adestian, Yuda. (2015). "Pengaruh Dewan Komisaris, Dewan Direksi, Dewan Komisaris Independen, Komite Audit dan Ukuran Perusahaan pada Kinerja Perusahaan Perbankan yang Listing di BEI Pada Tahun 2012- 2014.”

Darmadji, Tjiptono dan Hendy M. Fakhruddin. (2012). "Pasar Modal di Indonesia: Pendekatan Tanya Jawab”. Edisi Ketiga. Jakarta: Salemba Empat.

Darmawati, et al. (2005). "Hubungan Corporate Governance dan Kinerja Perusahaan". Jurnal Riset Akuntansi Indonesia. Vol. 8, No. 1; 65-81.

Dewayanto, Toto (2010). "Pengaruh Mekanisme Good Corporate Governance Terhadap Kinerja Perbankan Nasional (Studi pada Perusahaan Perbankan yang Terdaftar di Bursa Efek Indonesia Periode 2006-2008)". Fokus Ekonomi. Vol. 5 No. 2; 108.

Effendi, Muh. Arief. (2016). The Power of Good Corporate Governance. Edisi 2. Jakarta: Salemba Empat.

Fauzan, et al. (2012). "Pengaruh Struktur Kepemilikan dan Kinerja Keuangan Early Warning system Terhadap nilai Perusahaan (Studi pada Perusahaan Asuransi yang Terdaftar di Bursa Efek Indnesia)", Vol. 2, No. 1; 66.

Ghozali, Imam (2013). Aplikasi Analisis Multivariate dengan Program SPSS. Edisi Ketujuh. Semarang: Badan Penerbit Universitas Dipenogoro.

Ghozali, Imam (2016). Aplikasi Analisis Multivariate Dengan Program IBM SPSS 23. Semarang: Badan Penerbit Universitas Diponegoro.

Hanas, Azwar. (2009). Pengaruh Dewan Komisaris, Dewan Direksi dan Komite Audit terhadap Good Corporate Governance. Skripsi. Hal. 17.

Hardiningsih, P. \& R.M. Oktaviani. (2012). "Determinan Kebijakan Hutang Dalam Agency Theory dan Pecking Order Theory”, Vol. 1; 14.

Indah, et al. (2012). "Prinsip-prinsip Good Corporate Governance Pada Perusahaan Asuransi". Jurnal Dinamika Sosial Budaya. Vol. 14, No. 2; 142-148.

Komite Nasional Kebijakan Governance (KNKG). 2006. "Pedoman Umum Good Corporate Governance Indonesia". Indonesia : KNKG

Kusumaningtyas, T.K. (2015). "Pengaruh Good Corporate Governance Terhadap Nilai Perusahaan yang Terdaftar Pada Indeks Sri-Kehati”, Vol. 4, No. 7; 1-3.

Liana, Lie. (2009). 'Penggunaan MRA dengan Spss untuk Menguji Pengaruh Variabel Moderating terhadap Hubungan antara Variabel Independen dan Variabel Dependen". Jurnal Teknologi Informasi DINAMIK. Vol XIV, No. 2; 92.

Mutiara, N.A dan B.R. Kartawinata. (2014). "Pengaruh Capital Expenditure terhadap Tingkat Laba dengan Kinerja Perusahaan Sebagai Variabel Moderator (Pada Perusahaan Jasa 
Telekomunikasi yang terdaftar di Bursa Efek Indonesia Periode 2009-2013).

Nuraina, E. (2012). "Pengaruh Kepemilikan Institusional dan Ukuran Perusahaan Terhadap Kebijakan Hutang dan Nilai Perusahaan (Studi Pada Perusahaan Manufaktur yang Teraftar di BEI)". Vol. 1, hlm. 51- 70.

Nuswandari, C.(2009)."Pengaruh Corporate Governance Perception Index Terhadap Kinerja Perusahaan Pada Perusahaan yang Terdaftar di Bursa Efek Jakarta". Jurnal Bisnis dan Ekonomi (JBE). Vol. 16, No. 2: 70-84.

Permanasari, I. (2010). "Pengaruh Kepemilikan Manajemen, Kepemilikan Institusional dan Corporate Social Responsibility terhadap Nilai Perusahaan". Skripsi Universitas Diponegoro: Semarang.

Subago \& P. Bangun. (2014). "Dampak Dari Praktik Good Corporate Governance Terhadap Firm Value".

Suci, Y.F. \& S. Khairani. (2009). "Pengaruh Penerapan Prinsip Good Corporate Governance Terhadap Kinerja Perusahaan Pada PT Kereta Api (PERSERO) Divisi Regional III Sumatera Selatan".

Sugiyono. (2012). “Memahami Penelitian Kualitatif”. Bandung: Alfabeta

Suhartanti, Tutut. (2015). "Pengaruh Good Corporate Governance terhadap Nilai Perusahaan dengan Kinerja Keuangan sebagai Variabel Moderating”. Jurnal Ilmu \& Riset Akuntansi. Vol. 4, No.8, Hal. 11.

Susanti, R. (2014). "Pengaruh Kepemilikan Manajemen, Kepemilikan Institusional dan Corporate Social Responsibility Terhadap Nilai Perusahaan”. Vol. 3, No. 1.

Tarjo. (2008). "Pengaruh Konsentrasi Kepemilikan Institusional dan Leverage terhadap Manajemen Laba, Nilai Pemegang Saham serta Cost of Equity Capital." Simposium Nasional akuntansi XI. Pontianak.

Tumirin. 2007. "Analisis Penerapan Good Corporate Governance dan Nilai Perusahaan”. Jurnal BETA. Vol. 6, No.1.

Wibowo, Soni. (2015). "Pengaruh Kepemilikan Manajerial,Kepemilikan Institusional, Kebijakan Dividen dan Kebijakan Hutang terhadap Nilai Perusahaan". Tesis. 